\title{
Investigation of EMG Signals in Lower Extremity Muscle Groups During Robotic Gait Exercises
}

\author{
EsmaUzunhisarcıklı ${ }^{*}$, Mehmet Bahadır Çetinkaya ${ }^{2}, \mathrm{Uğur} \mathrm{Fidan}^{3}$, İsmail Çalıkuşu4 \\ ${ }^{1}$ Kayseri University, Vocational High School, Department of Biomedical Device Technology, Kayseri, Turkey (ORCID: 0000-0003-2821-4177) \\ ${ }^{2}$ Erciyes University, Engineering Faculty, Department of Mechanotronic , Kayseri, Turkey (ORCID: 0000-0003-3378-4561) \\ ${ }^{3}$ Afyon Kocatepe University, Engineering Faculty, Department of Biomedical Enginering, Afyon, Turkey (ORCID: 0000-0003-0356-017X) \\ 4 Nevsehir Hacıbektaş Veli University, Vocational High School, Department of Biomedical Device Technology,Nevşehir, Turkey (ORCID: 0000-0002-6640-7917)
}

(This publication has been presented orally at HORA 2019 congress.)

(First received 1 August 2019 and in final form 24 October 2019)

(DOI: $10.31590 /$ ejosat.637577)

ATIF/REFERENCE: Uzunhisarcıklı, E., Çetinkaya, M. B. Fidan, U. \& Çalıkuşu, İ. (2019). Investigation of EMG Signals in Lower Extremity Muscle Groups During Robotic Gait Exercises. European Journal of Science and Technology, (Special Issue), 109-118.

\begin{abstract}
Many people have been exposed to lower extremity function losses due to neurological, pathological or traffic accidents. In the physical therapy and rehabilitation of these patients, treatment programs based on robotic systems have started to be preferred instead of conventional methods. In robotic gait rehabilitation, mobilized lower extremity exoskeletons such as Rewalk or un-mobilized lower extremity exoskeletons such as RoboGait are used. It is important to evaluate the rehabilitation process in patients with lower extremity problems. Measurement of surface electromyogram (EMG) signals during the treatment process give information about the functional activities of the muscles. Obtained information plays an important role in determining the intention of patient motion in musculoskeletal design and musculoskeletal activities of the musculoskeletal. Changes in muscle activation timing and amplitude during the use of lower extremity exoskeleton can be determined by analysis of EMG. In this study, muscles involved in walking movement during robotic rehabilitation were examined. The examined iliopsoas, gluteus maximus, gluteus medius muscles provide flexion, extension and abduction movements of the hip, while the medial gastrocnemius and tibialis anterior muscles perform flexion and dorsiflexion movements of the foot. During the gait, the knee joint patency is controlled by the Vastus Medialis and Biceps Femoris muscles. In this study, while 6 patients with lower limb dysfunction were walking on the RoboGait device, the muscle activation potentials obtained from 7 different muscle groups were transferred to the computer simultaneously and wirelessly and displayed in the Matlab environment. The EMG signals measured with the MicroCor Lab device are shaped according to the activation of the muscles during walking. The electrode placement plan is critical for the analysis of EMG signals, and an appropriate electrode placement plan was obtained as a result of the study. Examined measured signals by following with the electrode placement plan, the maximum gluteus and iliopsoas muscles responsible for the extension and flexion movements of the hips are more effective during walking. Gletous maximum muscle was found to be the most effective muscle in walking while the iliopsoas muscle group was involved in the first movement of the leg. As a result of this study, these findings will help to follow the development of the treatment process and to develop EMG controlled mobilized lower extremity exoskeletons.
\end{abstract}

Keywords: Lower Extremity, Robotic Gait, EMG, Gait Analysis, Biotelemetry

\section{Robotik Yürüme Egzersizleri Sırasında Alt Ekstremite Kas Gruplarındaki EMG İşaretlerinin İncelenmesi}

Öz

Birçok kişi nörolojik, patolojik veya trafik kazası gibi nedenlerle alt eksremite fonksiyon kayıplarına maruz kalmaktadır. Bu hastaların fizik tedavi ve rehabilitasyonunda konvaksiyonel yöntemler yerine robotik sistemlere dayalı tedavi programları tercih edilmeye başlanmıştır. Robotik yürüme rehabilitasyonun da Rewalk gibi mobilize alt ekstremite dış iskeletleri veya RoboGait gibi sabit alt ekstremite dış iskeletleri kullanılmaktadır. Alt ekstremite sorunu yaşayan hastalarda rehabilitasyon sürecinin değerlendirilmesi önem arz etmektedir. Tedavi sürecinde yüzey elektromiyogram (EMG) işaretlerinin ölçülmesi kaslarının fonksiyonel aktiviteleri hakkında bilgi vermektedir. Elde edilen bu bilgiler dış iskelet tasarımında hasta hareketi niyetinin belirlenmesinde ve dış iskeletin kas aktiviteleri üzerinde önemli rol oynamaktadır. Alt ekstremite dış iskeletlerinin kullanımı sırasında kas aktivasyon zamanlaması ve genliğindeki değişiklikler, EMG'nin analizi ile ortaya çıkarılabilmektedir. Bu çalışmada, robotik rehabilitasyon sürecinde yürüme hareketi sırasında

\footnotetext{
* Corresponding Author: Erciyes University, Vocational High School, Department of Biomedical Device Technology, Kayseri, Turkey, ORCID: 0000-0003-2821-4177, uzunhise@,kayseri.edu.tr
} 
görev alan kaslar incelenmiştir. İncelenen ilipsoas, Gluteus Maksimus, Gluteus Medius kasları kalçanın fleksiyon, ekstansiyon ve abdüsksiyon hareketlerini sağlarken Medial Gastrokinemus ve Tibialis Anterior kasları ayağın fleksiyon ve dorsifleksiyon hareketlerini gerçekleştirmektedir. Yürüme fazı sırasında diz eklem açıklığı ise Vastus Medialis ve Biseps Femorus kasları ile kontrol edilmektedir. Çalışmada alt ekstremitede fonksiyon yetersizliği olan 5 hastanın RoboGait cihazı üzerinde yürürken 7 farklı kas grubundan alınan kas aktivasyon potansiyelleri eş zamanlı ve kablosuz olarak bilgisayara aktarılmış ve Matlab ortamında görüntülenmiştir. MicroCor Lab cihazı ile ölçülen EMG sinyalleri yürüme sırasında kasların aktivasyonuna göre şekillenmiştir. EMG işaretlerinin analizinde elektrot yerleşim planı kritik öneme sahip olup çalışma sonucunda uygun elektrot yerleşim planı elde edilmiştir. Elektrot yerleşim planına uygun olarak ölçülen işaretler incelendiğinde yürüme fazının gerçekleştirilmesi sırasında kalçanın ektansiyon ve fleksiyon hareketlerini sorumlu Gletous maximum ve İlipsioas kaslarının daha etkin olduğu ölçülmüştür. Gletous maximum kasının yürümede en etkili kas olduğu görülürken İlipsioas kas grubunun bacağın ilk hareketinde yer aldığ 1 EMG işaretlerinin analiz sonucunda belirlenmiştir. Çalışma sonucunda elde edilen bu bulgular hem tedavi sürecinde ki gelişimin takip edilmesinde hemde EMG kontrollü mobilize alt ekstremite dış iskeletlerin geliştirilmesinde yardımcı olacaktır.

\section{Anahtar Kelimeler: Alt Ekstremite, Robotik Yürüme, EMG, Yürüme Analizi, Biyotelemetri.}

\section{Introduction}

Treatment programs based on robotic systems have started to be preferred instead of traditional methods in physical therapy and rehabilitation. The main purpose of the Physical Therapy and Rehabilitation (PTR) process is to restore gait ability and adaptation to normal living conditions. Weak muscles and nerve pathways can be activated with PTR (Antonucci \& Paolucci, 2018). Robotic rehabilitation systems are categorized as nonmobile and mobile systems. Non-mobile systems are known as the walking orthosis, while mobile systems are generally known as the lower extremity exoskeleton (AbdulKareem, Adila, \& Husi, 2018). Research has shown that robotic therapy is more beneficial than conventional systems in the rehabilitation of patients such as brain injury, spinal cord injury, Parkinson's disease, multiple sclerosis and cerebral palsy (Schwartz \& Meiner, 2015).

Examined the studies in the literature, it is seen that lower extremity exoskeleton are designed to regain the gait of people with pathological gait disorders and to improve the performance of healthy individuals. It is seen that EMG signals from surface electrodes are used to detect the intention of motion for the control of these systems. In 2009, the study was conducted by Anne et al. with 19 elderly and 18 young participants and EMG signals during gait movement were compared. As a result of this study, it is seen that the elderly use the tibialis anterior and soleus muscles more than the younger ones, while the elderly benefit less from the soleus in fast gait (Schmitz, Silder, Heiderscheit, Mahoney, \& Thelen, 2009). In 2016, Mathews et al. Found that EMG activity was an important input in the intuitive control phase (Wilcox, Rathore, Ramirez, Loureiro, \& Carlson, 2016). In Chen study, it is showed that many control strategies were tested and tested with different approaches, mostly depending on the mobility of the target patient or end user. (Chen et al., 2016). Wu X. et al., With control strategies developed for people with immobility (for example, patients with complete spinal cord injury), aimed to enable the person's lower extremity active joints to walk on a predefined orbit. As a result of the study, it was concluded that the appropriate walking pattern was estimated for each person (Wu, Liu, Liu, Chen, \& Guo, 2018). In a study by Fernandes et al., A strong knee orthosis (PCO) was used to provide auxiliary commands based on the user's intention to move by electromyography (EMG) signalsAs a result, the assistive strategy developed has shown that the user can effectively follow the intention of movement and that patients with muscle strength now have the potential for gait rehabilitation (Fernandes et al., 2019). The measurement of activated muscles involved in motion and the application of assistive torque proportional to EMG signals in accordance with agonists are preferred as a strategic method in the control of robotic exoskeletal systems. (Yepes, Portela, Saldarriaga, Pérez, \& Betancur, 2019). The main purpose of the studies in the literature is to bring the gait closer to normal gait and to regulate muscle activation by reducing the energy costs required for gait.(Chen, Zi, Wang, Qin, \& Liao, 2019).

In this study, 7 muscle groups responsible for hip, knee and foot joint movements of 6 patients who were treated with robotic gait instead of healthy subjects were examined. The examined iliopsoas, gluteus maximus, gluteus medius muscles provide flexion, extension and abduction movements of the hip, while the medial gastrocnemius and tibialis anterior muscles perform flexion and dorsiflexion movements of the foot. In the gait phase, the knee joint patency is controlled by the Vastus Medialis and Biceps Femoris muscles. The electrode placement plan is critical for the analysis of EMG signals and an optimal electrode placement plan will be tried to be obtained as a result of the study. The main purpose of this study is to determine the relationship between walking EMG signs and muscle groups by time analysis of simultaneously measured EMG signals.

\section{Material and Methods}

Human gait is body motion that moves the individual's position forward from the previous position. Considered as steps are synchronous, investigating a gait cycle is sufficient to learn about the gait cycle. The gait cycle consists of two phases, single and double support phases. During the single support phase, one leg is in place while the other leg is swinging. The double support stage starts when the swinging foot reaches the floor and ends when the support foot is removed from the floor. 
Assuming that we start the walking cycle with the right leg as shown in Figure 1, the first leg is moved forward from the human's vertical position and the right leg is moved forward and placed on the ground. The first fixed walking step includes raising the left leg with one-foot support of the right leg until the left leg is repositioned. The second fixed walking step is similar to the first fixed walking step, but this step has one leg support of the left leg until the right leg is lifted and placed on the floor again. The repetition of continuous walking steps results in a continuous movement in the sagittal plane.

\section{Human Gait Cvcle}

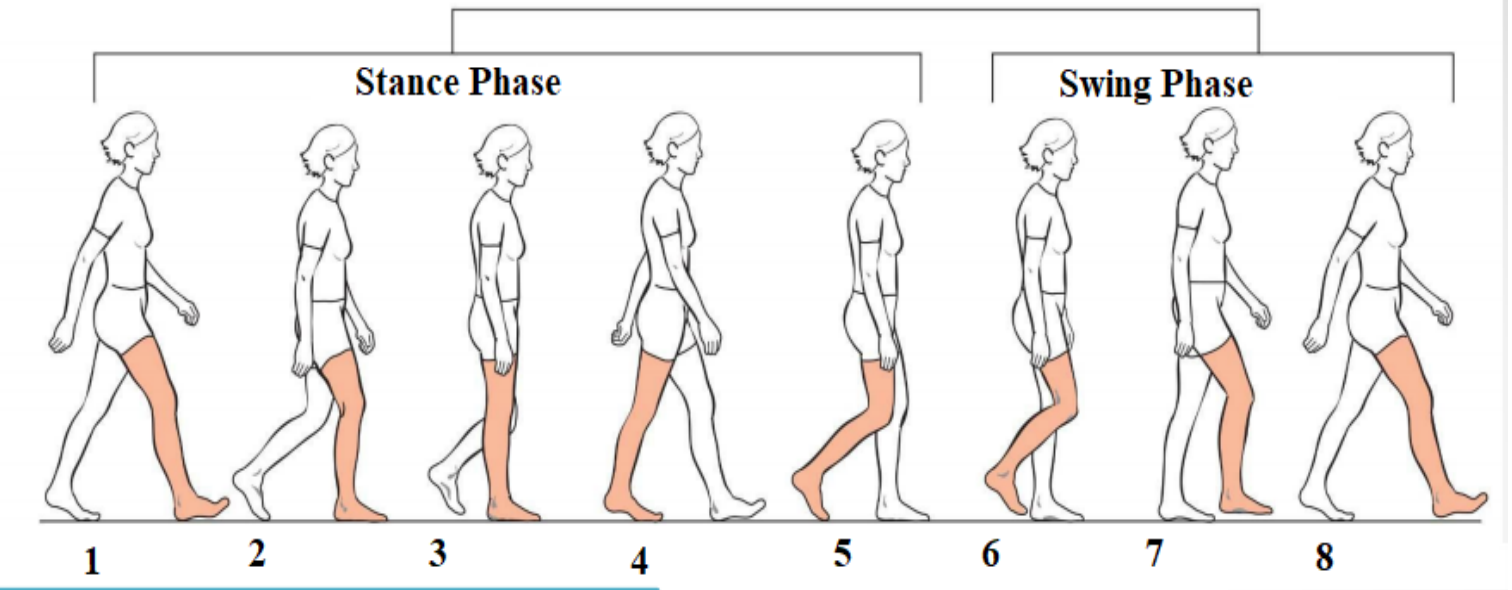

\begin{tabular}{l}
\hline Stance Phase \\
1- Initial Contact \\
2- Loading Response \\
3- Midstance \\
4- Terminal Stance \\
5- Preswing \\
\hline
\end{tabular}

Swing Phase

6-Initial Swing

7- Mid-Swing

8- Terminal Swing

Figure 1: Human Gait Cycle

The gait cycle is the time interval between two successive repetitions event of repetitive motion events. The human gait cycle is divided into two separate regions representing the period time as the foot is in contact with the ground. These are Stance faz1 (R) and Swing (S) phases. During the Stance phase, the foot touches the ground, the body mass is supported, and the body is then pushed forward in the subsequent posture stages. Figure 2 shows the reaction forces of the ground during the initial contact, loading response, mid-stance, terminal stance and pre-swing phases within the gait cycle.

Initial Contact: One foot touches the ground, the other called heel-stroke (HS) or footstrike

Loading response: The moment when the rest of the foot comes down to touch the ground and the full body weight is supported by the leg.

Midstance: The midstance is defined when the center of mass is directly above the ankle joint center.

Terminal stance: Heeling and Pressing End occurs when the soil starts to rise from the ground to push the heel forward.

Pre-swing: It occurs as the last contact event in the Stance phase. 


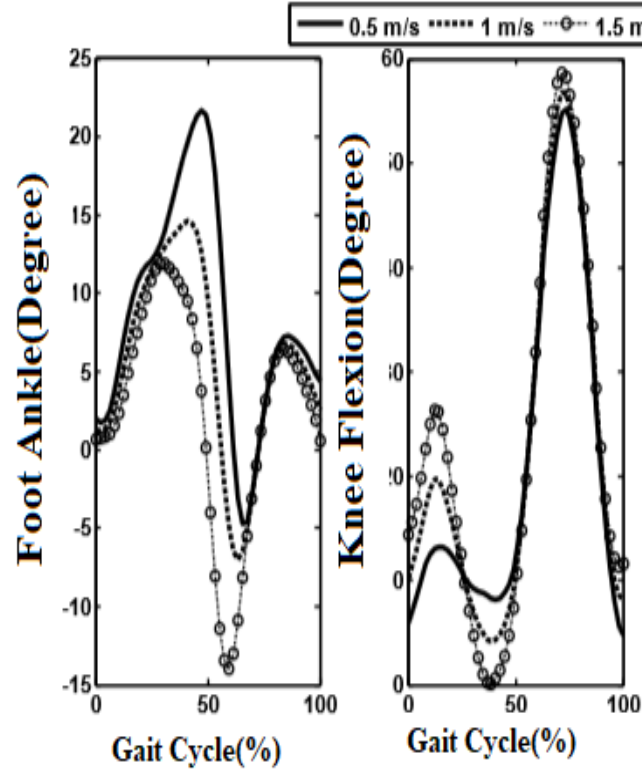

(a)

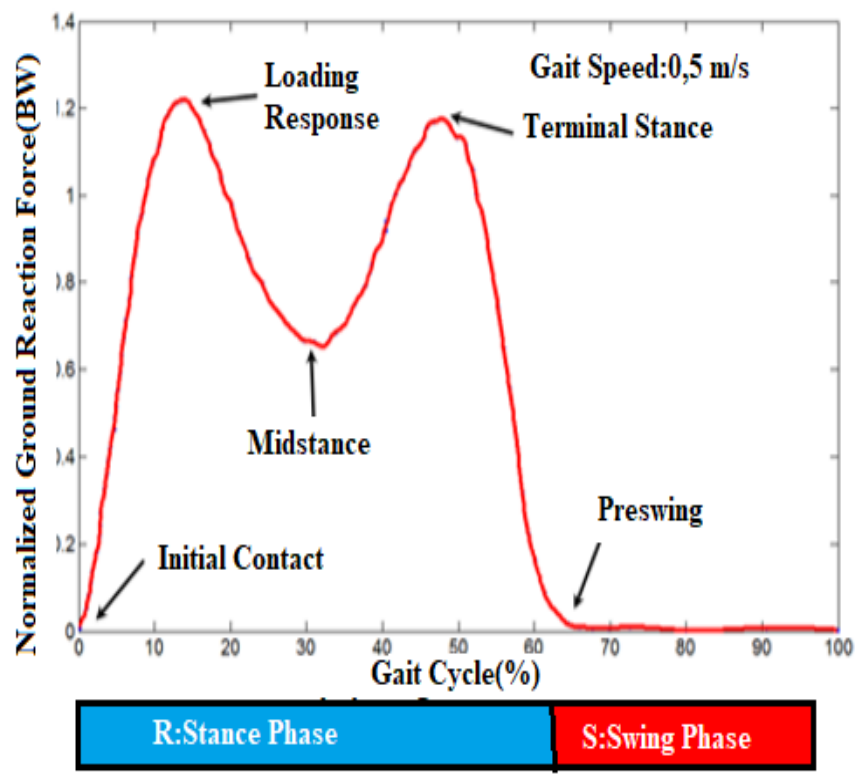

(b)

Figure 2. a) Hip, Knee Flexion and Foot Ankle Motion as degree b) Ground reaction forces in normal gait cycle.

Events occurring in a gait cycle are described as percentages rather than elapsed time. The first contact (HS) was determined as $0 \%$ and the following first contact of the same foot was determined as $100 \%$. During the normal gait cycle, the hip, knee and ankle joints are subjected to a series of movements. Hip movement is categorized into two basic movements. The first is the hip extension, occurs during the posture phase and has the primary role of stabilization of the trunk, and the second is the hip flexion that occurs during a swing. During the stance phase, knee limb stability is the main determinant, and in the oscillation phase, knee flexibility is the main factor of the freedom of extension of the limb.

\subsection{RoboGait}

RoboGait (Fig. 3) is an advanced gait system that presents the patient with a physiological gait pattern through a computer-controlled robotic orthosisRobogait is designed to be used in patients suffering from traumatic brain and spine injuries, stroke, neurological or orthopedic reasons. This system provides a safe and controlled environment for gait rehabilitation on the treadmill. The speed of the treadmill is synchronized with the exoskeleton and the rehabilitation program RoboGait reduces the number of physiotherapists required to work with a patient. The wearable robot increases the number of steps that can be achieved in each training session which ensures all consistent each together.

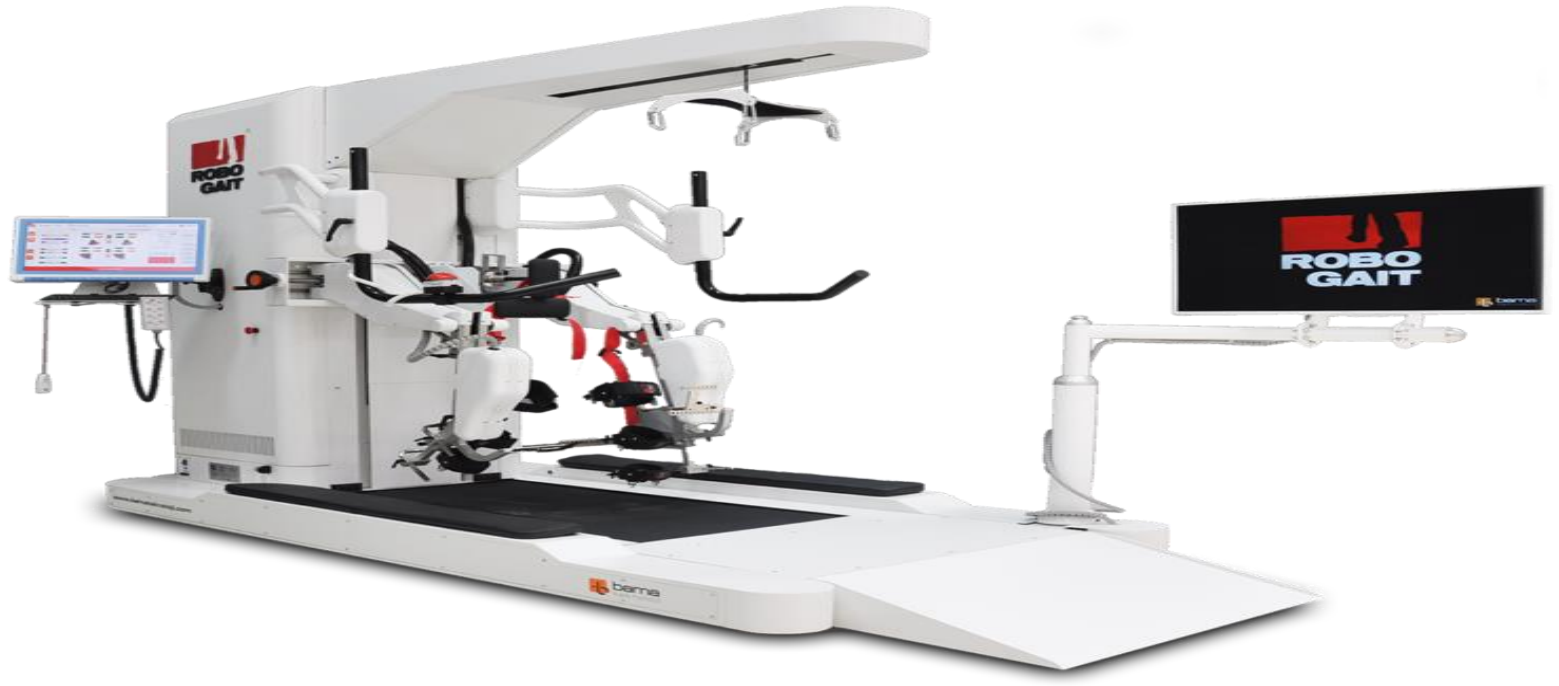

Figure 3.Robogait by BamaTechnology. 


\subsection{Effective Lower Extremity Muscle Groups in Gait}

Although there are 34 muscles in the lower extremities, there are only 7 muscle groups that are effective in walking. The position of the muscle groups in the anatomical structure and which movements are responsible are given in Table 1. Knowing the position of these muscle groups is important during the measurement of electromyogram (EMG) signals with surface electrodes.

Table 1. Effective Lower Extremity Muscle Groups in Gait.

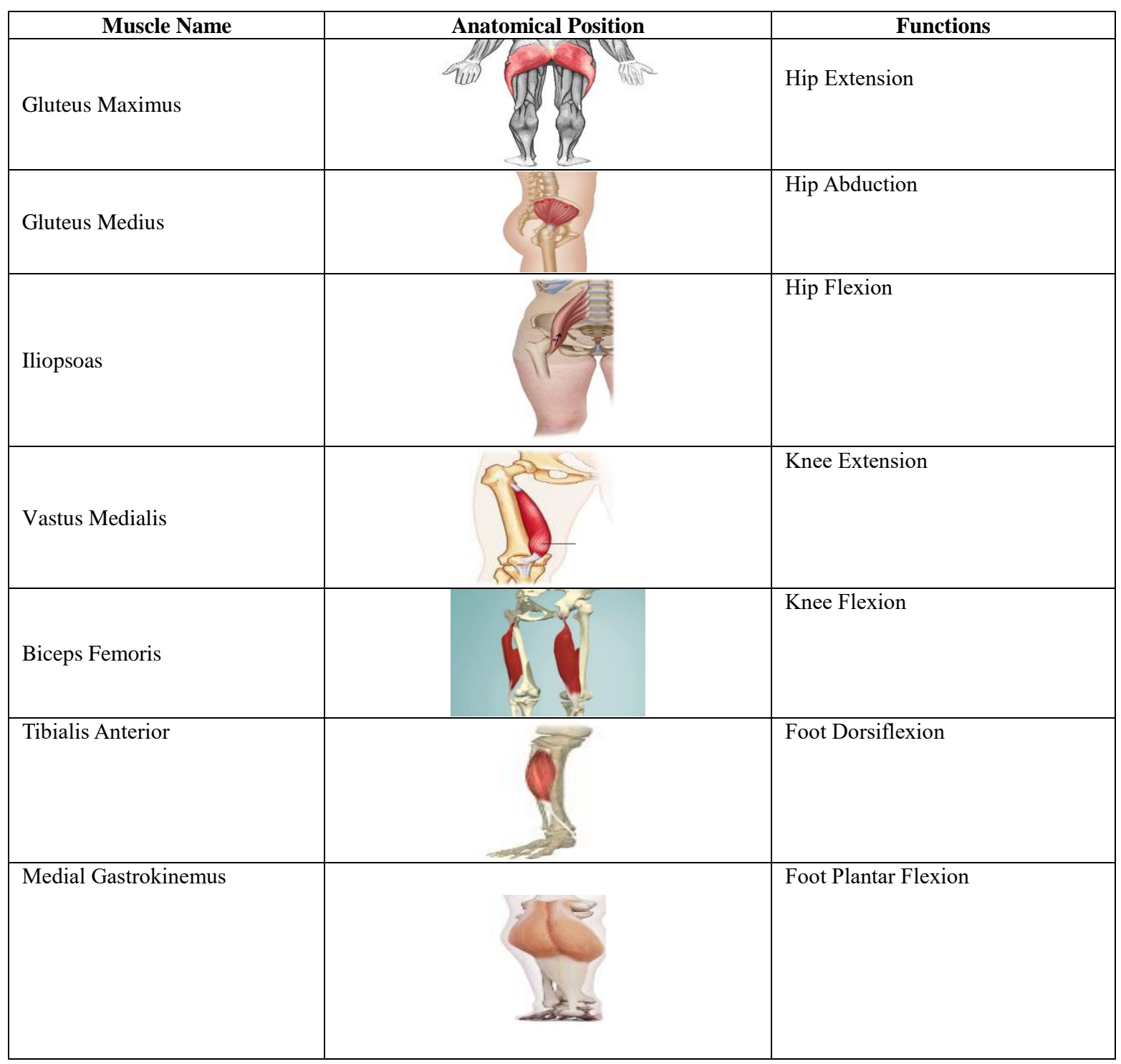

\subsection{EMG Analysis of Lower Limb Muscle Groups Using Robotic Gait System}

The block diagram of the system established for EMG analysis of lower extremity muscle groups is given in Figure 4. In this study, while 6 patients with lower limb dysfunction were walking on the RoboGait device, the muscle activation potentials obtained from 7 different muscle groups were transferred to the computer simultaneously and wirelessly and displayed in the Matlab environment. The EMG signals measured with the MicroCor Lab device are shaped according to the activation of the muscles during walking. 


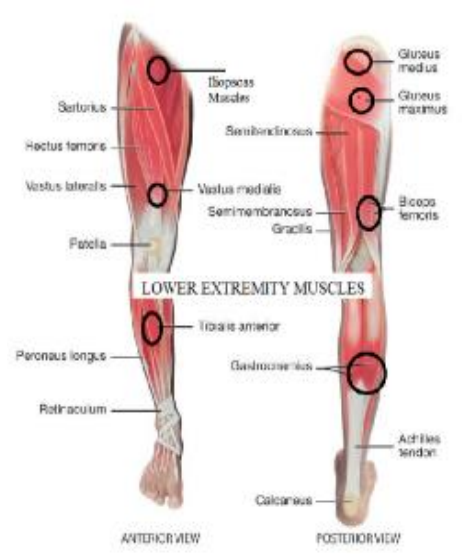

DEVELOPING EMG ANALYSING SYSTEM OF LOWER EXTREMITY MUSCLES USING ROBOTIC GAIT SYSTEM
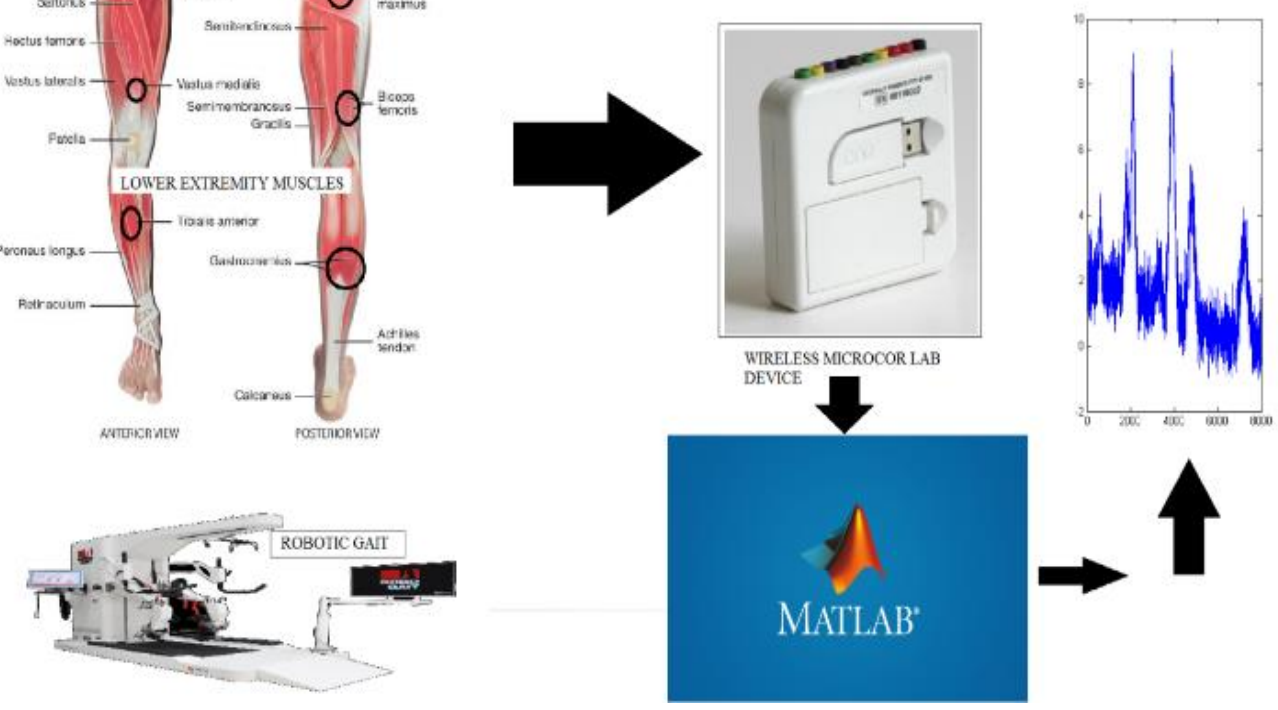

Figure 4. EMG analysing system of lower extremity muscles using robotic gait system.

\subsection{MicroCor ECG/EMG Measurement Device and Electrode Placement}

Designed as a portable MicroCor biosignal device is remarkable with its minimal dimensions and lightweight. The device is originally designed for electrocardiogram (ECG) signals. However; it provides to receive EMG, EEG, EOG, etc. physiological signals to the computer using Matlab based MicroCor Lab software written by the company. The device is used for receiving signals of leg muscles in robotic gait due to portable. Although the device is designed for 12-channel ECG, EMG signals can be received separately from 8 channels physiologically. The right leg electrode, be used as a reference, is connected to the knee cap or patella to prevent the base shift of the EMG signals. The left leg was left unused for signal reception. The connection of the cables is shown below. Figure 5 shows the locations of the disposable EMG surface electrodes shown by the rounds.

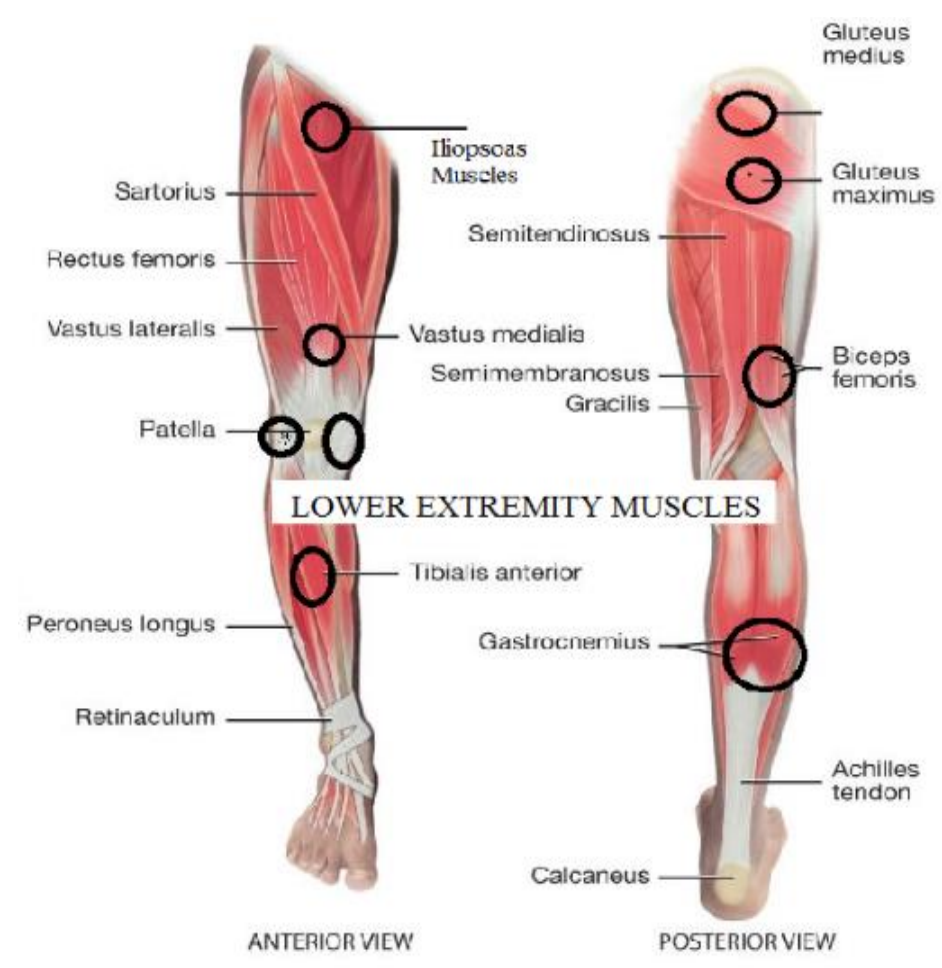

Figure 5. Electrode Placement Plan 


\section{Results and Discussion}

In this study, EMG signals of six patients with lower extremity problems were measured and are given Table 2. The EMG signals were taken from the right leg with the help of surface electrodes that were generated during exercise on the RoboGait walking robot. The examined iliopsoas, gluteus maximus, gluteus medius muscles provide flexion, extension and abduction movements of the hip, while the medial gastrocnemius and tibialis anterior muscles perform flexion and dorsiflexion movements of the foot. Gluteus maximus, gluteus medius, tibialis anterior muscles are seen that activate at the end of the stance phase and during swing phase activity. During the Stance phase, the effective muscle was found to be Vastus Medialis due to stepping on the ground. Also, the Tibialis Anterior muscle is one of the most active muscles during walking. The examined activity of the tibialis anterior muscle, it was seen that the artifact signal formed during each step. The contraction of the biceps femoris muscle is observed immediately after the tibialis anterior muscle. Besides, it was observed that the artifact formed in the anterior of the tibialis occurs simultaneously in the gluteus maximum.

Table 2. EMG signals of Lower Extremity Muscles.

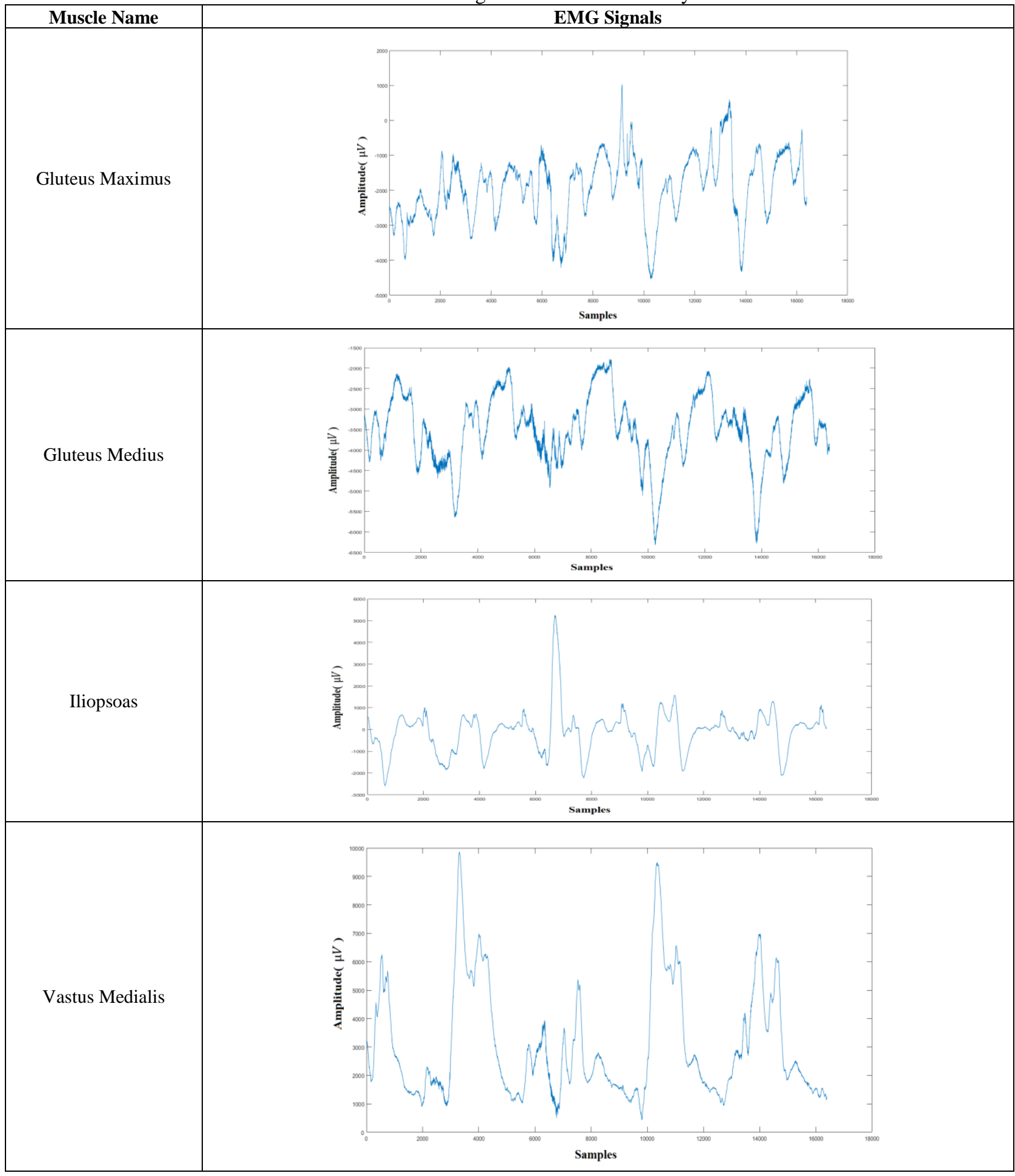




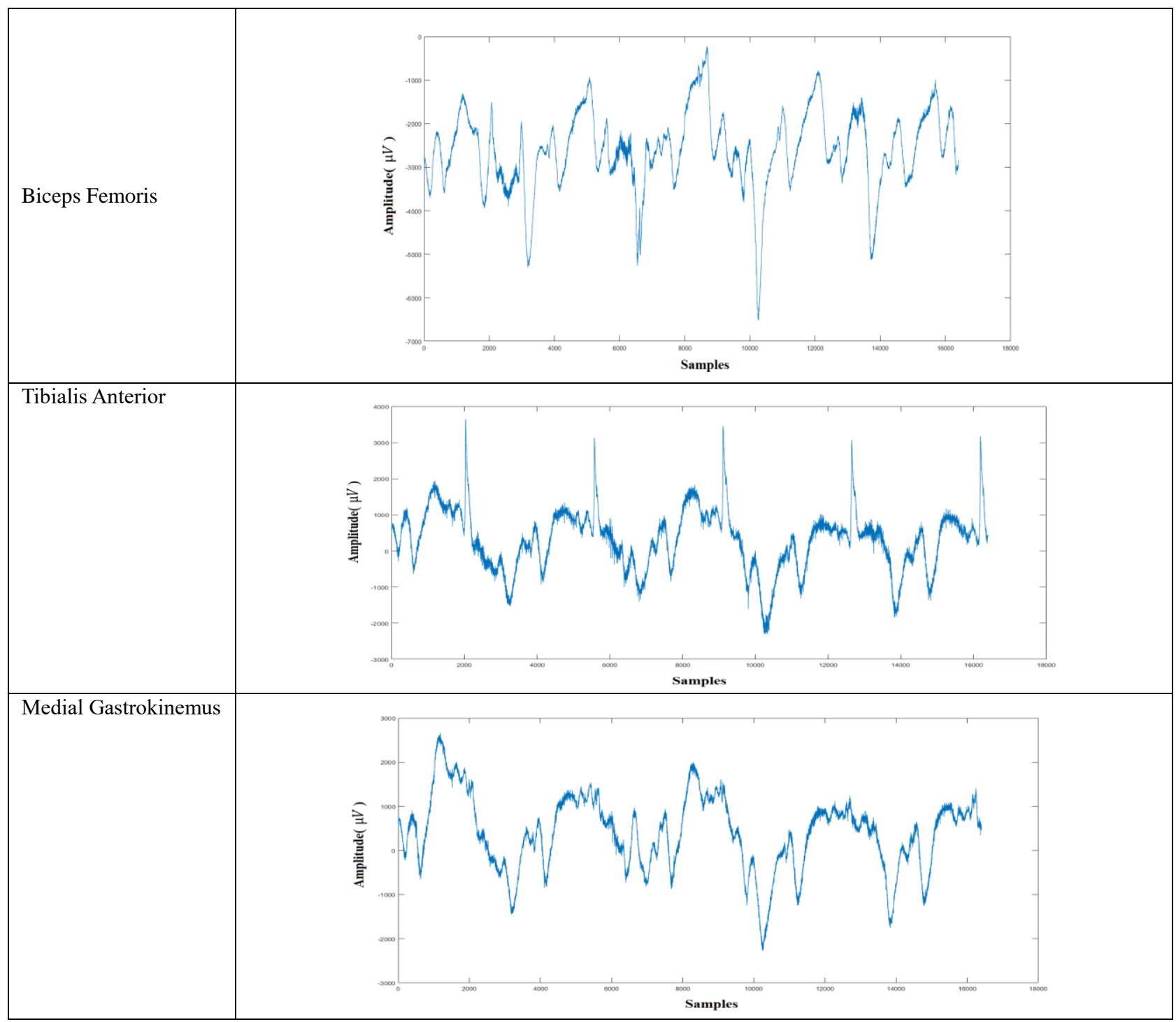

Unlike literature, EMG of 7 different muscles was taken at the same time according to a single point. Since the MicroCOR EMG device used records 550 samples per second, signals between $0-550 \mathrm{~Hz}$ are obtained. A second ground electrode is also connected to the patella to ensure that the reference values of the signals are the same. The most important result of the findings is that the tibialis anterior muscle is the most active in the stance phase and produces a separate needle tip artifact in the signal (Figure 6). Also, this artifact is shown in the gluteus maximus muscle at about the same time. It seems that these signals may be used to plan gait movement in the lower extremity exoskeleton. This artifact, which occurs in the tibialis arterior and occurs when each right leg hits the ground, can be used to calculate the number of walking steps. The time between these artifact signals can be calculated by using Equation 1,2 and 3. The time interval between the signals used in the calculation is given in Figure 6.

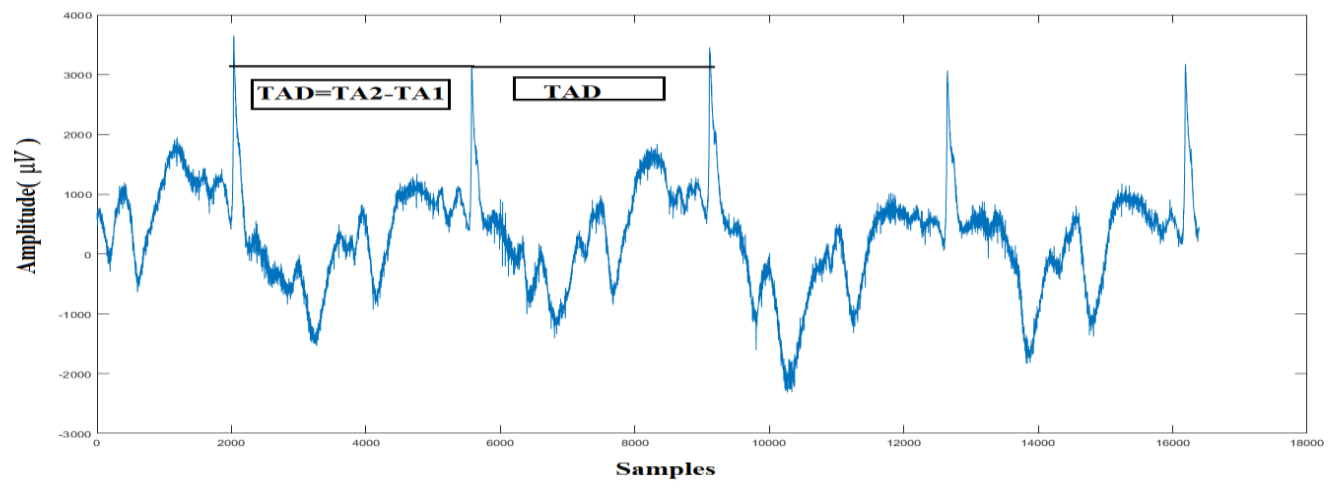

Figure 6. EMG signal of Tibialis anterior 


$$
\begin{array}{cc}
\text { TAD }=\text { TA2 }- \text { TA1 } & \text { Equation(1) } \\
\text { Step Time for a Leg }=\frac{(\text { second peak sample order }- \text { first peak sample order })}{550} & \text { Equation(2) } \\
\text { Steps for Minute }=\frac{120}{\text { Step Time for Leg }} & \text { Equation (3) }
\end{array}
$$

where, TA1 and TA2 show the sampling order of the signals, while TAD gives the difference in the sampling order between them. The robotic gait speeds are presented in Table 3 which were obtained with the equations 1,2 and 3.

Table 3. Patients' Gait Speed

\begin{tabular}{|l|l|l|}
\hline Patient Order & Step Time for a Leg & Steps for Minute \\
\hline 1 & 5.85 & 20 \\
\hline 2 & 5.60 & 21 \\
\hline 3 & 4,92 & 24 \\
\hline 4 & 6.26 & 19 \\
\hline 5 & 6.45 & 19 \\
\hline 6 & 6.13 & 20 \\
\hline
\end{tabular}

To test the accuracy of the calculation, images of 6 patients (Figure 7) were taken with GoPro Hero4 and the step duration was calculated. As a result, the human walking cycle time calculated with artifacts in Tibialis and the time calculated with the image were very close to each other. The correlation between EMG and video analysis was 95.66 and the variance was 0.157 . In the calculations, it was seen that more meaningful results could be obtained by increasing the number of sample patients.

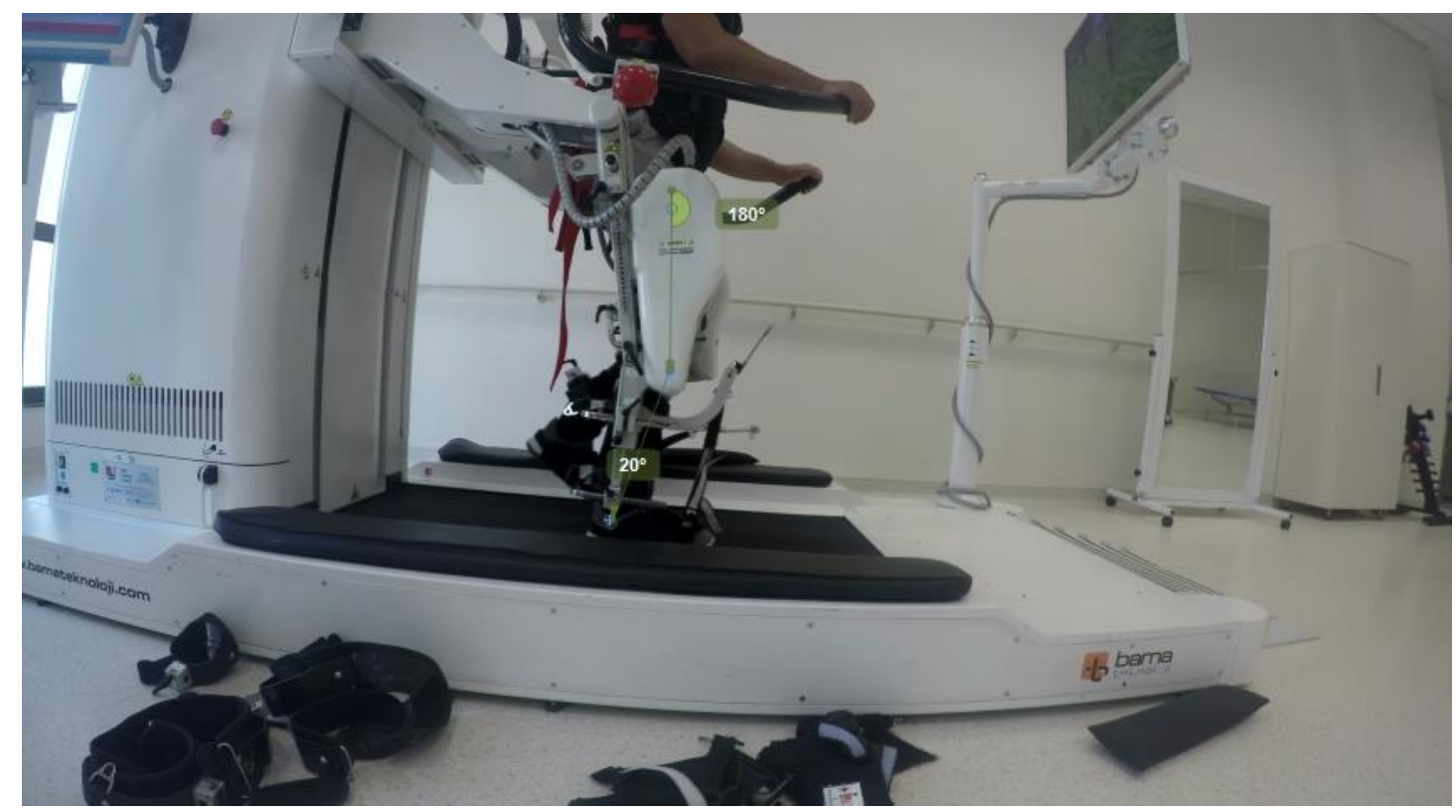

Figure 7. Image analysis in Robotic Gait.

\section{Conclusions and Recommendations}

In this study, signals from 6 patients with lower extremities were received and analyzed during robotic walking exercise over 7 muscle groups in walking. Gluteus maximus muscle was the most effective muscle in walking, while the iliopsoas muscle group was observed in the first movement of the leg. It has been concluded that Iliopsoas and Gluteus can be used to determine the intention to move maximum muscle signals. However, it has been observed that these signals can be examined by applying techniques such as linear envelope and RMS. In the following studies, linear envelope, RMS, PSD techniques can be applied separately or together to examine the effect of EMG on robotic gait and the effect of EMG on motor control. As a result of these findings, it is considered that these findings will help to follow the progress of the treatment process and to develop EMG controlled mobilized lower extremity exoskeletons. 


\section{Acknowledge}

We would like to thank Erciyes Scientific Research Projects Office for financial support. In addition, we would like to thank Adana City Hospital Management for its contribution to the Ethics Committee. In particular, we would like to thank the Renaissance Business Services who own and allow the use of the RoboGait device and Fimer Private Health Services responsible for the use of the device. We would like to thank Dr. Turgay Özcüler and Dr.Halit Fidancı for their contribution to the evaluation of EMG signals.

\section{References}

AbdulKareem, A. H., Adila, A. S., \& Husi, G. (2018). Recent trends in robotic systems for upper-limb stroke recovery: A low-cost hand and wrist rehabilitation device. Paper presented at the 2018 2nd International Symposium on Small-scale Intelligent Manufacturing Systems (SIMS).

Antonucci, G., \& Paolucci, S. (2018). Tailored, Technological Therapy: Physician and Therapists Point of View on Robotic Rehabilitation. Paper presented at the Converging Clinical and Engineering Research on Neurorehabilitation III: Proceedings of the 4th International Conference on NeuroRehabilitation (ICNR2018), October 16-20, 2018, Pisa, Italy.

Chen, B., Ma, H., Qin, L.-Y., Gao, F., Chan, K.-M., Law, S.-W., . . Liao, W.-H. (2016). Recent developments and challenges of lower extremity exoskeletons. Journal of Orthopaedic Translation, 5, 26-37.

Chen, B., Zi, B., Wang, Z., Qin, L., \& Liao, W.-H. (2019). Knee exoskeletons for gait rehabilitation and human performance augmentation: A state-of-the-art. Mechanism and Machine Theory, 134, 499-511.

Fernandes, P. N., Figueredo, J., Moreira, L., Félix, P., Correia, A., Moreno, J. C., \& Santos, C. P. (2019). EMG-based Motion Intention Recognition for Controlling a Powered Knee Orthosis. Paper presented at the 2019 IEEE International Conference on Autonomous Robot Systems and Competitions (ICARSC).

Schmitz, A., Silder, A., Heiderscheit, B., Mahoney, J., \& Thelen, D. G. (2009). Differences in lower-extremity muscular activation during walking between healthy older and young adults. Journal of electromyography and kinesiology, 19(6), 1085-1091.

Schwartz, I., \& Meiner, Z. (2015). Robotic-assisted gait training in neurological patients: who may benefit? Annals of biomedical engineering, 43(5), 1260-1269.

Wilcox, M., Rathore, A., Ramirez, D. Z. M., Loureiro, R. C., \& Carlson, T. (2016). Muscular activity and physical interaction forces during lower limb exoskeleton use. Healthcare technology letters, 3(4), 273-279.

Wu, X., Liu, D.-X., Liu, M., Chen, C., \& Guo, H. (2018). Individualized gait pattern generation for sharing lower limb exoskeleton robot. IEEE Transactions on Automation Science and Engineering, 15(4), 1459-1470.

Yepes, J. C., Portela, M. A., Saldarriaga, Á. J., Pérez, V. Z., \& Betancur, M. J. (2019). Myoelectric control algorithm for robot-assisted therapy: a hardware-in-the-loop simulation study. Biomedical engineering online, 18(1), 3. 